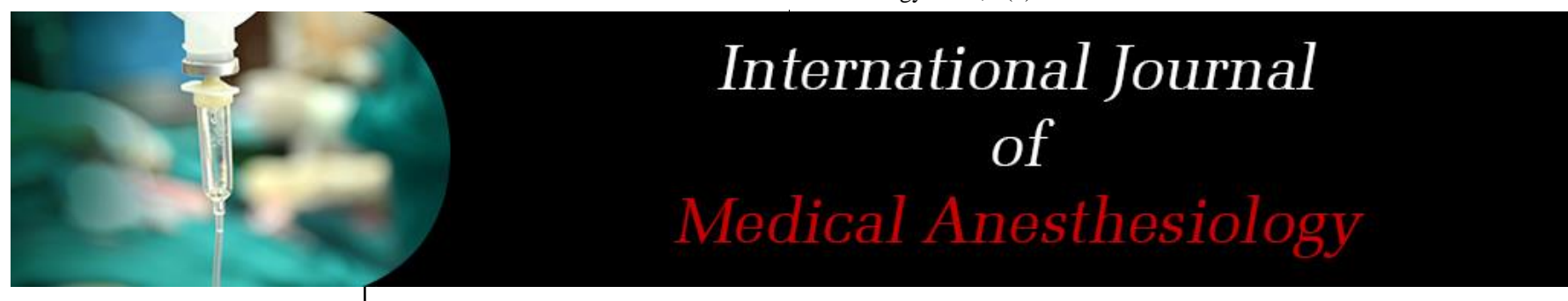

E-ISSN: 2664-3774

P-ISSN: 2664-3766 www.anesthesiologypaper.com IJMA 2020; 3(1): 114-119 Received: 19-11-2019 Accepted: 23-12-2019

Dr. Balasubramanian Associate Professor, Department of Anesthesiology, Trichy SRM Medical college Hospital Research Centre, Trichy, Tamil Nadu, India

Dr. Arathi Satheesh DNB (Anesthesia), FNB (Critical care) Consultant Critical Care, Ananthapuri Hospitals \& Research Institute, Trivandrum, Tamil Nadu, India
Corresponding Author: Dr. Balasubramanian Associate Professor, Department of Anesthesiology, Trichy SRM Medical college Hospital Research Centre, Trichy, Tamil Nadu, India

\section{A prospective study of comparing efficacy of combined clonidine to intrathecal hyperbaric bupivacaine and bupivacaine alone in post-operative analgesia}

\section{Dr. Balasubramanian and Dr. Arathi Satheesh}

DOI: https://doi.org/10.33545/26643766.2020.v3.i1b.78

\section{Abstract}

Background: Objective of the is to compare the efficacy of combined clonidine to intrathecal hyperbaric bupivacaine and bupivacaine alone on post operativie analgesla in lower limb ortho surgeries and the side effects of clonidine.

Methodology: To assess efficacy of 2 doses of intrathecal clonidine added to bupivacaine for postoperative pain relief following orthopedic surgeries of lower limb. This was a randomized, double blind, controlled study involving 75 patients divided into three groups $\mathrm{C}, \mathrm{C} 1, \mathrm{C} 2$ of 25 each.

Results: In our study, the mean duration of postoperative analgesia was $158.60 \mathrm{~min}$ in group $\mathrm{C}$ as compared to $349.20 \mathrm{~min}$ in group $\mathrm{C} 1$ and $623.56 \mathrm{~min}$ in group $\mathrm{C} 2$. This showed that clonidine produces dose dependent increase in the duration of postoperative analgesia

Conclusion: Addition of clonidine to intrathecal bupivacaine prolonged the duration and efficacy of postoperative analgesia, but increased the incidence of mild side effects.

Keywords: post op analgesia, clonidine, bupivacaine, intrathecal

\section{Introduction}

Postoperative pain is unique by its transitory nature, which makes it more amenable to therapy. There are several methods of postoperative pain relief. They are NSAIDs, opioids, through intravenous, intramuscular, subcutaneous, intrathecal, transdermal, transmucosal and regional nerve blocks using local anaesthetics, cryoanalgesia etc. Intrathecal clonidine, when used for labour analgesia and caesarean section, did prolong the duration of analgesia, but was associated with increased incidence of hypotension and sedation. So the study is a double blinded study to compare the effect of clonidine addition with bupivacaine and the complications.

\section{Aims of the study}

1. To compare the effect of addition of two different doses of clonidine to intrathecal hyperbaric bupivacaine and bupivacaine alone on post operativie analgesla in patients following lower limb orthopaedic surgeries.

2. To find out the incidence of side effects of clonidine which includes sedation, dryness of mouth, nausea, vomiting, bradycardia, hypotension and respiratory depression.

\section{Materials \& Methods}

Place of study: Trichy SRM Medical College Trichy with approval from Institutional Ethics Committee and written informed consent from all patients who participated in the study. It is a prospective, double blind randomized controlled study.

\section{Inclusion criteria}

1. Patients posted for elective orthopaedic surgeries of lower limb

2. Patients belonging to ASA PS 1 and 2 category.

3. Age group 20 to 60 years

4. Body weight 40 to $75 \mathrm{~kg}$

5. Height 150 to $180 \mathrm{cms}$ (assessed by measuring length) 


\section{Exclusion criteria}

1. History of allergy to local anesthetics and NSAIDs

2. Patients using alpha receptor antagonist, beta receptor antagonist, calcium channel blockers and angiotension converting enzyme inhibitors.

3. Patients with cardiac arrhythmias

4. History of spinal surgery

5. Patients with history of acid peptic disease

6. Patients with spinal deformity, peripheral neuropathy and on anticoagulant therapy.

7. Patient refusal

8. Duration of surgery lasting $>2$ hours

\section{Methods}

As per the criteria mentioned above, 75 patients posted for elective orthopaedic surgery of lower limb were selected and randomly allocated into three groups. C, C1, C2 of 25 each.

A thorough preoperative evaluation was done on the day before surgery to select patients satisfying the criteria. Basic investigations - haemoglobin estimation, blood grouping, urine routine, random blood sugar and renal function test were done in all patients. The anthropometric parameters and vitals were recorded.

\section{Anesthetic technique}

Patient was brought to the operation theatre. Monitors for HR, NIBP, ECG and SPO2 were attached and baseline values were recorded. Oxygen administered at 5 litre per min through simple face mask. IV access was secured using $18 \mathrm{G}$ cannula in the non-dominant hand and preloading was done with $10 \mathrm{ml}$ per $\mathrm{kg}$ normal saline.

Patient was placed in lateral position. Under strict asepsis, subarachnoid block was performed at 1.3/1.4 interspace using $25 \mathrm{G}$ Quincke spinal needle by a midline approach. After clear CSF tap, the drug was injected into subarachnoid space.

Patients belonging to Group C2 received $2.2 \mathrm{ml}(11 \mathrm{mg})$ of $0.5 \%$ hyperbaric bupivacaine with $60 \mathrm{mcg}$ clonidine intrathecally (total volume $2.6 \mathrm{ml}$ ).

Clonidine was taken in insulin syringe so as to add the drug precisely.

The study medication was administered by an anaesthesiologist not involved in the care of the patient or collection of data. The principal investigator blind to the identity of study medication monitored, managed the patients and collected the data.

After the subarachnoid injection, patients were immediately turned on to supine position. Heart rate, blood pressure, SPO2 and respiration were monitored every $2 \mathrm{~min}$ for the first 20 minutes and every 5 min thereafter, till completion of surgery. Surgery was started when the sensory level of blockade reached T10 dermatome.

No. intraoperative sedation was administered. Intraoperative fluid maintenance was done with normal saline. Hypotension (defined as a systolic blood pressure $<90 \mathrm{~mm}$ $\mathrm{Hg}$ or fall of $30 \%$ or more from baseline, whichever was higher) was treated with $6 \mathrm{mg}$ of IV ephedrine. Bradycardia (defined as a heart rate $<60$ per minute) was treated with $0.6 \mathrm{mg}$ of IV atropine. Sensory levels were rechecked during the procedure and peak sensory level attained was noted. Adverse effects such as nausea, vomiting, dryness of mouth, headache, sedation and respiratory depression (defined as $\mathrm{RR}<8$ per min) were recorded. Patients who had nausea/ vomiting were treated with injection Ondansetron $4 \mathrm{mg}$ IV.

Sedation was assessed by Ramsay sedation score.

1. Awake and anxious, agitated or restless, or both.

2. Awake, co-operative, oriented or tranquil.

3. Awake, responds only to commands.

4. Asleep, brisk responds only to commands.

5. Asleep, sluggish responds to light glabellar tap or loud noise.

6. Asleep, no response to light glabellar tap or loud noise.

If the patients expressed a need for additional analgesia because of intraoperative pain, injection fentany 150 meg IV was given. If block was inadequate, general anesthesia was administered. Post operatively, pulse rate, BP and respiration were monitored at hourly intervals for $6 \mathrm{hrs}$ and then at $9 \mathrm{hrs}, 12 \mathrm{hrs}, 24 \mathrm{hrs}$. The duration of complete motor blockade of the lower extremities and presence of side effects were noted.

\section{The intensity of motor block assessed by bromage scale}

1. Free movement of legs and feet.

2. Just able to flex knees with free movement of feet.

3. Unable to flex knees but with free movement of feet.

4. Unable to move legs or feet.

Post-operative analgesia was assessed using verbal numeric rating scale at hourly intervals for $6 \mathrm{hrs}$ and then at $9 \mathrm{hrs}, 12$ hrs and $24 \mathrm{hrs}$.

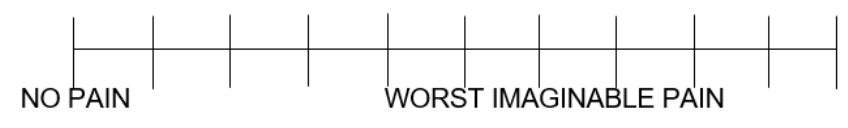

\section{Verbal numeric rating scale}

The duration of post-operative analgesia was calculated as the time interval between the completions of surgery to the appearance of pain corresponding to VNRS score of 4. Rescue analgesia was given with injection diclofenac $75 \mathrm{mg}$ IM. If pain was still not relieved, injection tramadol $50 \mathrm{mg}$ IM was given. The number of rescue analgesics required in $24 \mathrm{hr}$ period was also noted.

Table: Seventy five patients were included in the study with 3 groups of 25 patients each.

\begin{tabular}{|c|c|c|}
\hline $\begin{array}{c}\text { Group } \\
\text { C }\end{array}$ & - & $\begin{array}{c}\mathbf{2 2} \mathbf{~ m l ~ o f ~ 0 . 5 \%} \text { Hyperbaric bupivacaine alone + } \\
\mathbf{0 . 4 m l} \text { sterile normal saline. }\end{array}$ \\
\hline $\begin{array}{c}\text { Group } \\
\text { C1 }\end{array}$ & - & $\begin{array}{c}22 \mathrm{ml} \text { of } 0.5 \% \text { Hyperbaric bupivacaine }+30 \mathrm{mcg} \\
\text { clonidine }+0.2 \mathrm{ml} \text { sterile normal saline. }\end{array}$ \\
\hline $\begin{array}{c}\text { Group } \\
\text { C2 }\end{array}$ & - & $\begin{array}{c}2.2 \mathrm{ml} \text { of } 0.5 \% \text { Hyperbaric bupivacaine }+60 \mathrm{mcg} \\
\text { clonidine. }\end{array}$ \\
\hline \multicolumn{2}{|c|}{ Group C was the control grup. } \\
\hline \multicolumn{3}{|c|}{ Group C1 and C2 were the study groups. } \\
\hline
\end{tabular}

The observations were tabulated and analysed using appropriate statistical tools. The comparison of normally distributed continuous variables such as demographic data, vital parameters and time parameters among the groups were performed by means of analysis of variance (ANOVA). Nominal categorical data among the groups such as peak sensory level, sedation and other side effects among the groups were compared using Chisquare analysis. Inter group comparison was done using Bonferroni. $\mathrm{P}$ value $<0.05$ was considered statistically significant. 


\section{Observation \& Analysis \\ Demographic data \\ Peak sensory level}

Table 1: Data expressed as number of patients attaining the peak sensory level and the percentage in each group

\begin{tabular}{|c|c|c|c|c|c|c|}
\hline \multirow{2}{*}{$\begin{array}{c}\text { Peak Sensory } \\
\text { Level }\end{array}$} & \multicolumn{2}{|c|}{ Group C } & \multicolumn{2}{c|}{ Group C1 } & \multicolumn{2}{c|}{ Group C2 } \\
\cline { 2 - 7 } & Number & \% & Number & $\%$ & Number & $\%$ \\
\hline T4 & & & 1 & $4 \%$ & 10 & $40 \%$ \\
\hline T5 & & & 2 & $8 \%$ & 4 & $16 \%$ \\
\hline T6 & & & 6 & $12 \%$ & 8 & $32 \%$ \\
\hline T7 & & & 3 & $12 \%$ & 2 & $8 \%$ \\
\hline T8 & 7 & $28 \%$ & 7 & $28 \%$ & 1 & $4 \%$ \\
\hline T9 & 5 & $20 \%$ & 2 & $8 \%$ & & \\
\hline T10 & 13 & $52 \%$ & 4 & $16 \%$ & & \\
\hline
\end{tabular}

There is highly significant difference between patients in the 3 groups with respect to the peak sensory level reached follwoing.

Subarachnoid block. (Chi Squarea value $56.650 \&$ P value 0.000). The maximum sensory level reached was T8 in the control group as compared to T4 in the study groups. All patients in the control group had a peak sensory level between $\mathrm{T} 8$ and T10. Majority of patients in group $\mathrm{C} 1$ $(64 \%)$ had a peak sensory level between T6 and T8 and majority of patients in group C2 $(88 \%)$ had a peak sensory level between T4 andT6.

\section{Duration of Motor Block}

Table 2: Duration of motor block in 3 groups

\begin{tabular}{|c|c|c|c|}
\hline Parameters & Group C & Group C1 & Group C2 \\
\hline Duration of Motor Block & $129.56 \pm$ & $185.20 \pm$ & $232.40 \pm$ \\
(min) & 13.81 & 47.14 & 42.18 \\
\hline
\end{tabular}

Data expressed as mean \pm standard deviation. The mean duration of motor block in the control group was $129.56 \mathrm{~min}$ as compared to $185.20 \mathrm{~min}$ in group $\mathrm{C} 1$ and $232.40 \mathrm{~min}$ in group C2. There is statistically significant difference between patients in the 3 groups with respect to the duration of motor block following subarachnoid block ( $\mathrm{P}$ value $0.000)$.

\section{Duration of postoperative analgesia}

Time interval between completion of surgery and the time when the patient complains of pain corresponding to VNRS score of 4 was taken as the duration of postoperative analgesia.

Table 3a: Duration postoperative analgesia in 3 groups

\begin{tabular}{|c|c|c|c|}
\hline Parameters & Group C & Group C1 & Group C2 \\
\hline $\begin{array}{c}\text { Duration of } \\
\text { Postoperative } \\
\text { analgesia (in min) }\end{array}$ & $158.60 \pm 47.47$ & $349.20 \pm 150.57$ & $623.56 \pm 292.49$ \\
\hline
\end{tabular}

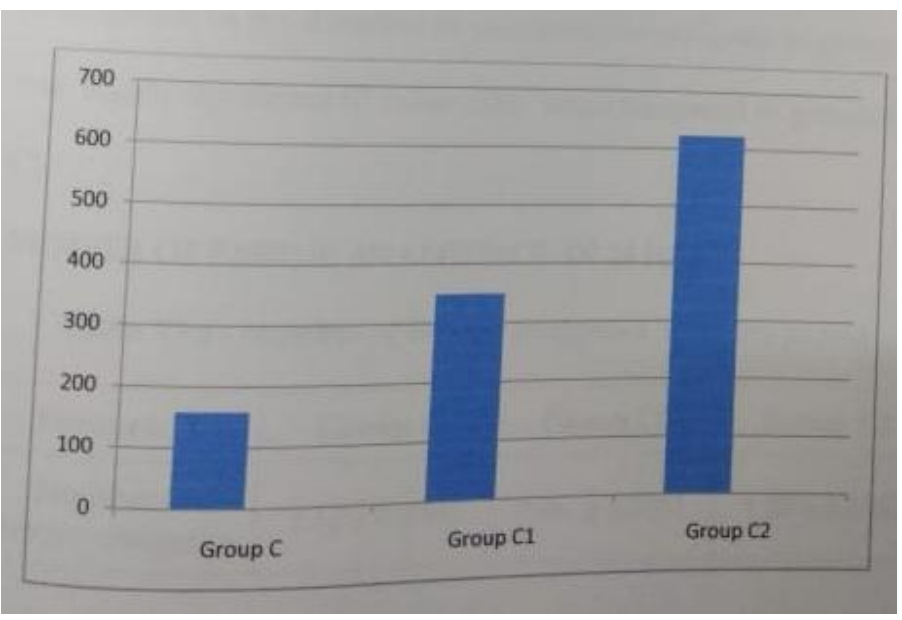

Fig 1: Duration postoperative analgesia in group $\mathrm{C}, \mathrm{C} 1, \mathrm{C} 2$

Data expressed as mean \pm standard deviation.

Table 3b: Comparison of mean duration of postoperative analgesia between groups

\begin{tabular}{|c|c|}
\hline Groups compared & P value \\
\hline $\mathrm{C} \& \mathrm{C} 1$ & 0.002 \\
\hline $\mathrm{C} 1$ \& 2 & 0.000 \\
\hline $\mathrm{C} \& \mathrm{C} 2$ & 0.000 \\
\hline
\end{tabular}

The mean duration of postoperative analgesia was 158.60 min in group $\mathrm{C}$ as compared to $349.20 \mathrm{~min}$ in group $\mathrm{C} 1$ and 623.56 min in group C2.

There was statistically significant different when the control group $\mathrm{C}$ was compared with the study group $\mathrm{C} 1 \& \mathrm{C} 2$. The prolongation in the duration of postoperative analgesia in group $\mathrm{C} 2$ was highly significant $(\mathrm{P}$ value. 000) when compared to groups $\mathrm{C} \& \mathrm{C} 1$.
Number of Rescue Analgesics in 24 Hrs

Table 4a: Number of Rescue analgesics in $24 \mathrm{hrs}$ period

\begin{tabular}{|c|c|c|c|}
\hline Parameters & Group C & Group C1 & Group C2 \\
\hline Number of Rescue & $2.12 \pm$ & $1.56 \pm$ & $1.28 \pm$ \\
analgesics & 0.6000 & 0.5831 & 0.6782 \\
\hline
\end{tabular}

Table 4b: Cross tab for rescue analgesia categories among 3 groups

\begin{tabular}{|c|c|c|c|c|c|c|}
\hline \multirow{2}{*}{$\begin{array}{c}\text { Rescue Analgesia } \\
\text { categories }\end{array}$} & \multicolumn{2}{|c|}{ Group C } & \multicolumn{2}{c|}{ Group C1 } & \multicolumn{2}{c|}{ Group C2 } \\
\cline { 2 - 7 } & Number & \% & Number & \% & Number & \% \\
\hline 1 or $<1$ & 3 & $12 \%$ & 12 & $48 \%$ & 17 & $68 \%$ \\
\hline 2 or $>2$ & 22 & $88 \%$ & 13 & $52 \%$ & 8 & $32 \%$ \\
\hline
\end{tabular}

$88 \%$ of patients in the control group $\mathrm{C}$ required 2 or more rescue analgesics in the $24 \mathrm{hrs}$ period as compared to $52 \%$ of patients in group $\mathrm{C} 1$ and $32 \%$ in group $\mathrm{C} 2.2$ patients in group $\mathrm{C} 2$ did not require any rescue analgesics during the 
$24 \mathrm{hr}$ study period.

Table 4c: Comparison of rescue analgesic requirements between groups

\begin{tabular}{|c|c|}
\hline Groups compared & P Value \\
\hline C \& C1 & 0.006 \\
\hline C1 \& C2 & 0.347 \\
\hline C \& 22 & 0.000 \\
\hline
\end{tabular}

There was statistically significant difference when the control group was compared with the study groups. There was highly significant difference when group $\mathrm{C}$ was compared to group $\mathrm{C} 2$ ( $\mathrm{P}$ value 0.000). The difference between the groups $\mathrm{C} 1$ and $\mathrm{C} 2$ was not statistically significant (P value 0.347 ).

\section{Sedation}

Table 5a: Sedation score in the 3 groups

\begin{tabular}{|c|c|c|c|}
\hline Parameters & Group C & Group C1 & Group C2 \\
\hline Sedation Score & $1.36 \pm 0.49$ & $1.64 \pm 0.70$ & $2.04 \pm 0.93$ \\
\hline
\end{tabular}

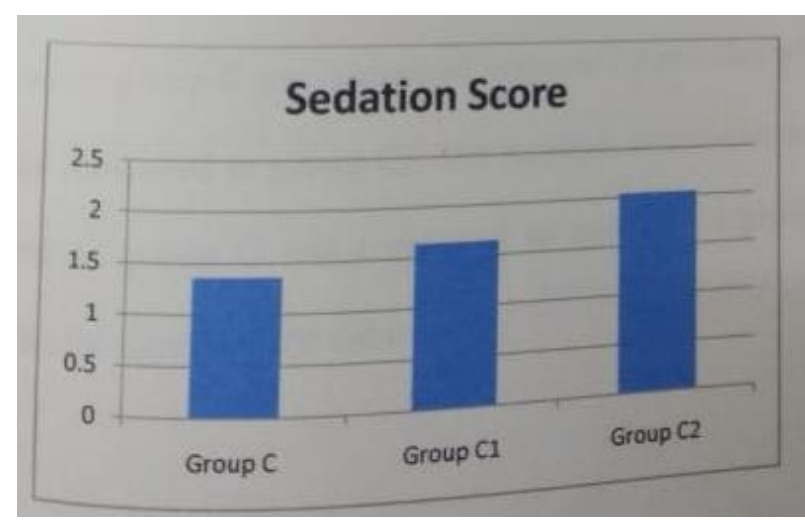

Fig 2: Sedation score in the 3 groups

Data expressed as mean \pm standard deviation.

Table 5b: Cross tab for sedation categories in 3 groups.

\begin{tabular}{|c|c|c|c|c|c|c|}
\hline \multirow{2}{*}{$\begin{array}{c}\text { Sedation } \\
\text { categories }\end{array}$} & \multicolumn{2}{|c|}{ Group C } & \multicolumn{2}{c|}{ Group C1 } & \multicolumn{2}{c|}{ Group C2 } \\
\cline { 2 - 7 } & Number & \% & Number & \% & Number & \% \\
\hline 2 or less & 25 & $100 \%$ & 22 & $88 \%$ & 18 & $72 \%$ \\
\hline 3 or more & & & 3 & $12 \%$ & 7 & $28 \%$ \\
\hline
\end{tabular}

All the patients in group $\mathrm{C}$ had a sedation score of 2 or less as compared to $88 \%$ in group $\mathrm{C} 1$ and $72 \%$ in group $\mathrm{C} 2$.

Table 5c: Comparison of sedation between groups.

\begin{tabular}{|c|c|}
\hline Groups compared & P value \\
\hline $\mathrm{C} \& \mathrm{C} 1$ & 0.540 \\
\hline $\mathrm{C} 1 \& \mathrm{C} 2$ & 0.171 \\
\hline $\mathrm{C} \& \mathrm{C} 2$ & 0.005 \\
\hline
\end{tabular}

There was no statistically significant difference in the sedation score when group $\mathrm{C}$ was compared to group $\mathrm{C} 1$ and also when group $\mathrm{C} 1$ was compared to group $\mathrm{C} 2$. The increase in sedation score when patients in group $\mathrm{C}$ was compared to patients in group C2 was statistically significant (P value 0.005).

\section{Cardiovacscular Side Effects}

Table 6: Comparison of cardiovascular side effects in 3 groups

\begin{tabular}{|c|c|c|c|c|c|c|c|}
\hline \multirow{2}{*}{ Parameters } & \multicolumn{2}{|c|}{ Group C } & \multicolumn{2}{c|}{ Group C1 } & \multicolumn{2}{c|}{ Group C2 } & P \\
& Number & \% & Number & \% & Number & \% & value \\
\hline 2 or less & 25 & $100 \%$ & 22 & $88 \%$ & 18 & $72 \%$ & 0.262 \\
\hline 3 or more & & & 3 & $12 \%$ & 7 & $28 \%$ & 0.114 \\
\hline
\end{tabular}

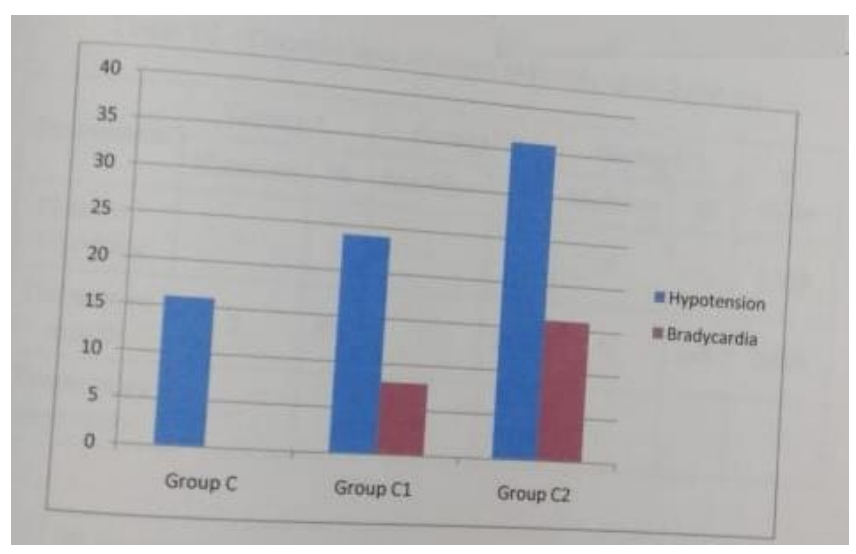

Fig 3: Comparison of rescue analgesic requirements between groups

Of the 75 patients studied, 19 patients developed hypotension following subarachnoid block. $16 \%$ of patients in group $\mathrm{C}$ developed hypotension as compared to $24 \%$ in group $\mathrm{C} 1$ and $36 \%$ in group $\mathrm{C} 2$. Though more patients in the study group developed hypotension when compared to control, this difference was not statistically significant $(\mathrm{P}$ value 0.262 ).

None of the patients in the control group developed bradycardia, whereas $8 \%$ of patients in group $\mathrm{C} 1$ and $16 \%$ of patients in group $\mathrm{C} 2$ developed bradycardia following subarachnoid block. The increase in the incidence of bradycardia in the study groups was not statistically significant (P value 0.114).

\section{Other Side Effects}

Table 7: Comparison of other side effects in 3 groups

\begin{tabular}{|c|c|c|c|c|c|c|c|}
\hline Parameters & \multicolumn{2}{|c|}{ Group C } & \multicolumn{2}{|c|}{ Group C1 } & \multicolumn{2}{|c|}{ Group C2 } & P \\
\cline { 2 - 7 } & Number & $\%$ & Number & $\%$ & Number & $\%$ & value \\
\hline $\begin{array}{c}\text { Nausea / } \\
\text { Vomiting }\end{array}$ & - & - & - & - & 2 & $8 \%$ & 0.128 \\
\hline $\begin{array}{c}\text { Dryness of } \\
\text { mouth }\end{array}$ & 2 & $8 \%$ & 7 & $28 \%$ & 9 & $36 \%$ & 0.058 \\
\hline $\begin{array}{c}\text { Respiratory } \\
\text { depression }\end{array}$ & - & - & - & - & - & - & - \\
\hline
\end{tabular}

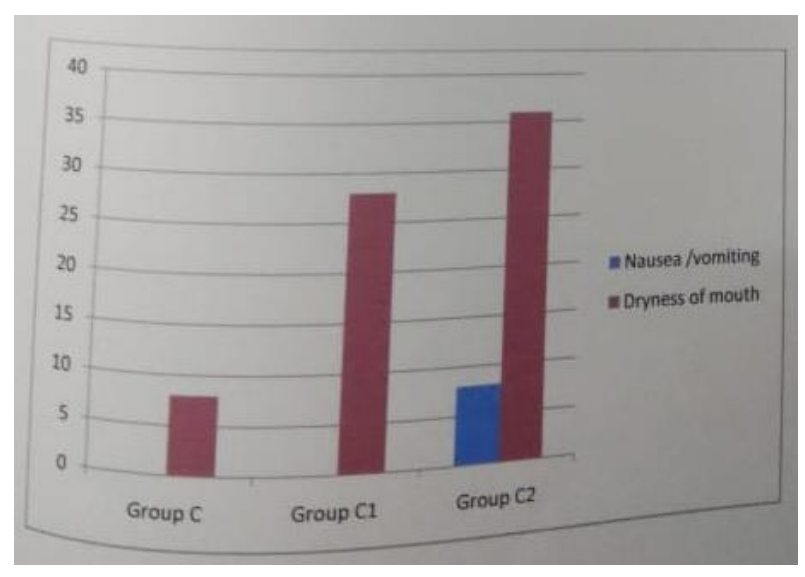

Fig 4: Comparison of other side effects in 3 groups 


\section{Discussion}

Only 2 patients included in the study had nausea / vomiting and they belonged to group $\mathrm{C} 2$, whereas none of the patients in groups $\mathrm{C} \& \mathrm{C} 1$ had vomiting.

18 among the 75 patients studied had dryness of mouth. This included 2 patients in group $\mathrm{C}(8 \%), 7$ patients in group $\mathrm{C} 1(28 \%)$ and 9 patients in group $\mathrm{C} 2(36 \%)$. The incidence of dryness of mouth was more among patients in the study groups, but this was not statistically significant $(\mathrm{P}$ value 0.058 ).

None of the patients included in the study developed respiratory depression. The respiratory rate was more than 12 per min in all patients.

Subarachnoid block is the anesthetic technique of choice for most lower limb orthopedic surgeries, mainly because it is easy and quick to perform provides fast onset and has a high success rate. It provides excellent intraoperative and postoperative analgesia. The duration of postoperative analgesia can be prolonged with the administration of spinal adjuvants such as clonidine, opioids, neostigmine etc.

Clonidine is a selective partial agonist at a2 adrenoreceptors. The analgesic effect following its intrathecal administration is mediated spinally through activation of post synaptic a2 receptors in substantia gelationsa of a spinal cord. The rationale behind intrathecal administration of clonidine is to achieve a high drug concentration in the vicinity of a2 adrenoreceptors in the spinal cord. It works by blocking the conduction of $\mathrm{A} \delta$ and $\mathrm{C}$ fibres, increases potassium conductance in neurons and intensifies conduction block of local anesthetics.

Clonidine is known to prolong the sensory and motor block of local anesthetics. It is inexpensive, easily available and suitable for intrathecal administration. Using intrathecal clonidine in place of opioids avoids problems of respiratory depression, nausea / vomiting, pruitus, urinary retention and abuse liability.

This study was done mainly to assess efficacy of 2 doses of intrathecal clonidine added to bupivacaine for postoperative pain relief following orthopedic surgeries of lower limb. This was a randomized, double blind, controlled study involving 75 patients divided into three groups of 25 each.

All three groups were comparable with regard to age, height, weight, physical status, duration of surgery as well as their preoperative vital parameters.

The maximum sensory level reached was T8 in the control group as compared to T4 in the study groups. This showed that addition of intrathecal clonidine increased the spread of sensory block and hence facilities the use of a lower dose of bupivacaine to attain the desired sensory block.

A similar study was conducted by Dobrydjov et al. in 45 patients posted for inguinal herniorrhaphy. Clonidine in doses of $15 \mathrm{mcg}$ and $30 \mathrm{mcg}$ were added to intrathecal hyperbaric bupivacaine. The peak sensory level was T10 in the control group as compared to T6 and T8 in the study groups. The results of the above mentioned study was comparable with that of our study.

In our study, the mean duration of block in the control group was $129.56 \mathrm{~min}$ as compared to $185.20 \mathrm{~min}$ in group $\mathrm{C} 1$ and $232.40 \mathrm{~min}$ in group C2. This showed that addition of clonidine to intrathecal bupivacaine potentiates the duration of motor blockade. This could be because, the a 2 agonists induce cellular modification in the ventral horn of the spinal cord (motor neuron hyperpolarization) and facilitate the local anesthetic action.
In a study conducted by B.S. Sethi et al., patients who received $1 \mathrm{mcg} / \mathrm{kg}$ intrathecal clonidine admixed with bupivacaine had a mean duration of motor blockade of 205 min as compared to $161 \mathrm{~min}$ in patients who received intrathecal bupivacine alone. The results of the above mentioned study was comparable with our study.

The prolonged motor blockade in the clonidine group facilitates longer orthopedic procedure such as bilateral arthroplasties or complex prosthesis replacements to be performed under subarachnoid block alone and obviates the need for an epidural block or general anesthesia. One drawback of this prolonged motor block is that it is not suitable for short procedures and in surgeries where early ambulation is desirable.

In our study, the mean duration of postoperative analgesia was $158.60 \mathrm{~min}$ in group $\mathrm{C}$ as compared to $349.20 \mathrm{~min}$ in group $\mathrm{C} 1$ and $623.56 \mathrm{~min}$ in group $\mathrm{C} 2$. This showed that clonidine produces dose dependent increase in the duration of postoperative analgesia. This is in agreement with a study conducted by Stephen Strebel et al. where clonidine in does $37.5 \mathrm{mcg}, 75 \mathrm{mcg}$ and $150 \mathrm{mcg}$ were added to intrathecal isobaric bupivacaine and found that the duration of sensory block was prolonged by the addition of intrathecal clonidine in a dose dependent manner.

The postoperative analgesia requirement in the $24 \mathrm{hr}$ study period was less in the clonidine groups when compared to the control. 2 patients who received $60 \mathrm{mcg}$ intrathecal clonidine did not require any rescue analgesics in the $24 \mathrm{hr}$ study period. Thus addition of clonidine improved analgesia and decreased the postopertative analgesic requirement.

The sedation score was higher in the clonidine group. Clonidine produces sedation due to its action in the locus corulus in brain stem. There is no significant difference in the sedation score when the control group was compared with the study group which received $30 \mathrm{mcg}$ clonidine, but there was significant increase in sedation score when compared to study group which received $60 \mathrm{mcg}$ clonidine. But this sedation was not associated with respiratory depression. All the patients included in the study had a respiratory rate more 12 per min. The sedative effect could be desirable in the perioperative period.

The incidence of hypotension and bradycardia is more in the clonidine group when compared to control, though the increase was not statistically significant. Most of the patients in the clonidine group who developed bradycardia / hypotension did so 45-60 min after the subrarachnoid block, the hemodynamic effects is due to the decrease in central sympathetic nervous system outflow produced by clonidine. Though the incidence of hypotension with $60 \mathrm{mcg}$ of clonidine was more than that produced by $30 \mathrm{mcg}$ clonidine it was not statistically significant.

Another major side effect of clonidine is dryness of mouth. It was present in $28 \%$ of patients in group $\mathrm{C} 1$ and $36 \%$ of patients in group $\mathrm{C} 2$ as compared to $8 \%$ in the control group. Though dryness of mouth was more in the clonidine group, it was not statistically significant.

None of the patients in the control group had nausea / vomiting. $8 \%$ of patients in group $\mathrm{C} 2$ had nausea / vomiting which was not statistically significant.

Addition of clonidine to intrathecal bupivacaine prolonged the duration and efficacy of postoperative analgesia, but increased the incidence of mild side effects. This increase in side effects was not statistically significant and could be effectively managed with medical treatment. Increasing the 
dose of clonidine from $30 \mathrm{mcg}$ to $60 \mathrm{mcg}$ produced significantly prolonged duration of postoperative analgesia without statically significant increase in the incidence of side effects.

\section{Conclusions}

- Addition of clonidine to intrathecal bupivacaine prolongs the duration of postoperative analgesia and decreases the analgesic requirement after lower limb orthopedic surgery. The maximum duration is seen with 60 mcg clonidine.

- Addition of intrathecal clonidine is associated with increase in side effects such as hypotension, bradycardia, sedation and dryness of mouth but not statistically significant.

\section{References}

1. Niemi L. Effects of intrathecal clonidine on duration of bupivacaine spinal anesthesia, hemodynamics and postoperative analgesia in patients undergoing knee arthrospcopy. Acta Anesthesiol Scand. 1994; 38:724-8.

2. De Negri P, Salvatore R, Visconti C, Devivo P, Mastronardi P. Spinal anesthesia with clonidine and bupivacaine in young humans: interactions and effects on cardiovascular system, Minerva Anesthesiology. 1997; 63:119-25.

3. Racle JP, Benkhadra A, Poy JY, Gleizal B, Prolongation of isobaric bupivacaine spinal anesthesia with epinephrine and clonidine for hip surgery in elderly. Anesth analg, 1987; 66:442-6.

4. Filos KS, Goudas LC, Patroni O Polyzou V. Intrathecal clonidine as a sole analgesic for pain relief after caesarian section. Anesthesiology. 1992; 77:267-74.

5. Stephen strebel, Jurg A, Gurzeler, Markus C, Schneider, Armin Aeschbach, Christopd H. Small dose intrathecal clonidine and isobaric Bupivacaine for orthopedic surgery: A Dose Response study. Anesth analg, 2004; 99:1231-8.

6. Klimscha W, Chiari A, Krafft P, Plattner O, Taslimi R, Mayer N, et al. Hemodynamic and Analgesic effects of clonidine added repetitively to continuous spidural and spinal blocks. Anesth Analg. 1995; 80:322-7.

7. Dobrydnjov, Axelsson K, Matthiesen P, Klockhoff H, Holmstrom B, Gupta A. et al. Clonidine combined with small dose bupivacaine during spinal anesthesia for inguinal herniorrhaphy: a randomized double blind study. Anesth Analg. 2003; 96:1496-503.

8. Alain Rochette, Olivier Raux, Rachel Troncin, Christophe Dadure, Regis Verdien, Xavier Capdevila. et al. Clonidine prolongs spinal anesthesia in newborns: A prospective dose ranging study. Anesth Analg, 2004; 98:56-9.

9. De Kock, Marc, Gautier, Philippe, Fanard, Luc Hody, Jean, Patricia. Intrathecal Ropivacaine and clonidine for ambulatory knee arthroscopy: A dose response study. Anesth Analg. 2001; 94:574-8. 